\title{
ЕКОАОГІЧНЕ ПРАВО
}

\author{
Удк 349.6 \\ DOI https://doi.org/10.32840/pdu.3-1.13
}

В. В. Шеховцов

кандидат юридичних наук, доцент кафедри екологічного права

Національного юридичного університету імені Ярослава Мудрого

\section{ФІЛОСОФСЬКО-ІСТОРИЧНІ АСПЕКТИ ТРАНСФОРМАЦІЇ СУСПІЛЬНОÏ СВІДОМОСТІ ЩОДО ТВАРИННОГО СВІТУ ЯК ОБ'ЄКТА ЕКОЛОГІЧНОГО ПРАВА}

У статті автором досліджено окремі правові та філософські аспекти становлення підходів до загального розуміння тварин як об'єктів правовідносин, випадки наділення їх за окремих соціально-історичних періодів додатковими якостями, що виходять за межі вчення про об'єкти прав.

Незважаючи на те, що законодавчо тварина безапеляційно віднесена до об'єктів права, дискусійні питання щодо можливості наділення ії певним обсягом правоздатності так чи інакше акцентуються для характеристики тварини в праві.

Встановлено, що за традиційними концепціями фауністичного права тварини зазвичай розглядалися як об'єкти прав, наданих їх власникам, але не як власники прав людини. Проте навіть як об'єкти тварини історично посідали значиме місце в загальній системі правових та соціальних відносин. Тварини в минулому являли значно більшу частку суспільного багатства, ніж нині.

Віднайшло філософське осмислення і питання класифікації тварин у категорії власності. Тварини юридично класифікуються як власність у більшості країн світу - це спадщина давніх систем права. Однак з тих пір наукові, філософські та культурні уявлення про тварин змінилися, тож має сенс переглянути доцільність майнового статусу тварин.

Дослідження показує, що, на думку деяких дослідників сучасності, обґрунтування для класифікації тварин як власності є слабким, i тому необхідно розпочати діалог про альтернативні варіанти їх правового статусу. Прихильники такої концепції стверджують, що сам факт того, що тварина біологічно не належить до людського виду, не перешкоджає тому, щоб їі класифікували як суб'єкт права.

Досягнуто висновку, що відповідно до сучасної вітчизняної правничої позиції тварини суб'єктами права бути не можуть. I нині сучасній українській правовій сфері не притаманні тенденції до змінювання чи корегування статусу таких об'єктів прав, як тварини, адже за переважаючою думкою вони виключаються з числа суб'єктів права через відсутність у них здатності до розумного мислення. Разом із тим наявність у тварин ознак, що виділяють їх із ординарного розуміння об'єкта правовідносин, притаманність їм атрибутів квазісуб'єктності є цілком допустимими.

Ключові слова: фауна, тваринний світ, об'єкт екологічного права, квазісуб'єкт, тварини як суб'єкти, правоздатність тварин, філософський аналіз правового статусу тварин.

Постановка проблеми. Фауна $є$ важливим регулювальним і стабілізаційним компонентом біосфери, що охороняється

(C) Шеховцов В. В., 2019 й раціонально використовується для задоволення духовних і матеріальних потреб громадян. Крім релігійного та культурного аспектів, з давніх часів тваринний світ був предметом господарського інтересу людей, 
об'єктом мисливського і рибного промислу, джерелом промислової, технічної, лікарської сировини, що викликає необхідність розглянути його представників як з об'єктної точки зору, так і квазісуб'єктної.

Наділення тварин правами набуває все більшого поширення у сучасному світі і знаходить своє відображення у працях багатьох дослідників, переважно іноземних. У вітчизняній науці цей сегмент наукової думки перебуває у зачатковому стані і тому потребує дослідження.

Аналіз останніх досліджень і публікацій. Теоретичною базою дослідження виступили праці вітчизняних та зарубіжних фахівців у галузі екологічного права і філософських наук, зокрема: В. Борейко, В. Петрової, П. Тихого, П. Сінгера, Р. Неша, К. Стоун та ін.

Окремими аспектами, присвяченими регулюванню фауністичних правовідносин, дослідженнями особливих ознак тваринного світу займалися відомі українські та зарубіжні вчені, такі як: В. Андрейцев, А. Гетьман, I. Каракаш, О. Колбасов, С. Константініді, С. Кравченко, В. Костицький, Н. Малишева, В. Мунтян, I. Перчеклій, В. Попов, С. Размєтаєв, П. Тихий, В. Шахов, Ю. Шемшученко, М. Шульга та інші.

Не вирішені раніше проблеми. y вітчизняній науці повного комплексного теоретичного дослідження таких об'єктів екологічного права, як тварини, не проводилось. Крім того, не було здійснено міжгалузевого аналізу статусу представників фауни. Здебільшого інтерес науковців у сфері екологічного права викликають проблеми правового регулювання суто об'єктів тваринного світу, а не тварин як об'єктів цивільних прав. За таких обставин багато теоретичних та практичних питань залишається без відповіді, ті чи інші аспекти правового регулювання в цій сфері досліджені поверхнево або взагалі не розглядалися.

Метою статті $\epsilon$ дослідження в історичній ретроспективі ставлення людського суспільства до тваринного світу, його вплив на формування культурних та ідеологічних уявлень людей, проведення аналізу наукових концепцій щодо можливості визнання тварини суб'єктом прав та доречність законодавчого закріплення цього у сучасних реаліях.

\section{Виклад основного матеріалу.} Для формування глибинного уявлення про тваринний світ як об'єкт екологічного права та осмислення його багатогранності необхідно вивчити філософські та тісно з ними пов'язані культурно-релігійні аспекти трансформації суспільної свідомості як основоположні чинники становлення теперішнього та формування майбутнього статусу тварин.

Оскільки древні люди, що жили в гармонії з природою, відчували свою близькість з тваринами набагато гостріше, ніж наші сучасники, то богів вони уявляли собі не тільки у вигляді людей, а й у вигляді тварин. 3 дерева або з каменю люди вирізали грубе зображення людини або тварини і вважали, що бог вселяється в цього ідола. Мисливці просили у богів удачу на полюванні, рибалки - тихої погоди і рясного улову, хлібороби - багатого врожаю [10, с. 72].

Досить цікавою $\epsilon$ класифікація форм шанування рослин і тварин, запропонована В. Борейко, які в своїй більшості мають екологічне звучання: 1) тотеми; 2) духи-господарі; 3) духи-покровителі (таємні союзи); 4) культ предків у вигляді тварин і рослин; 5) священні тварини і рослини. При цьому остання форма шанування - найвища [7, с. 53].

Протягом усієї своєї історії життя людина була нерозривно пов'язана з тваринами найтіснішим чином і певною мірою залежала від них. Тварини служили для людини джерелом їжі й одягу. Тварини попереджали про небезпеку, пророкуючи своєю поведінкою різноманітні зміни в навколишньому світі: шторми і бурі, повені, землетруси, виверження вулканів.

Із прирученням тварин у побуті стародавньої людини відбулися великі зміни. Тому в багатьох місцях стали шанувати бика, або тільця як божу силу, уявляючи собі, що божество вселяється в цю могутню і благодійну тварину. Наприклад, у Мемфісі і Геліополі - древніх столицях Єгипту, шанували священних биків Апіса і Мневіс. У Саккарі $\epsilon$ некрополь священних птахів - ібісів [11, с. 23].

На зорі розвитку людства тварини служили людині об'єктами для наслідування і шанування та не були для нього «братами 
меншими». Пам'ятники матеріальної культури епохи Стародавнього Світу: велика кількість скульптур і інших творів образотворчого мистецтва, що дійшли до нашого часу, стародавній живопис, представлений головним чином як розпис на стінах гробниць і храмів, на яких майстри-художники зображували міфологічні та побутові сцени, твори давньогрецьких письменників- історіографів, а також результати багаторічних досліджень в етнографічній науці, дають змогу говорити про те, що позиція ненасильства стосовно тварин існувала ще з давнини. Спочатку вона виявлялася на несвідомому рівні в шануванні тварин, перш за все в присвоєнні тваринам статусу «священні тварини» [10, с 76].

Необхідно відзначити, що питання ставлення до тварин, у тому числі захисту наданих їм прав, було продиктоване не лише турботою про них або бажанням поліпшити свою карму, як, наприклад, у країнах Стародавнього Сходу, а й усвідомленням людиною благотворного впливу гуманного поводження з тваринами на моральний стан соціуму. Ціла плеяда релігійних і філософських видатних особистостей: Піфагор Самоський, Діоген, Порфірій, Горацій, Овідій, Сенека та інші висловлювалася про необхідність поваги до тварин, неприпустимість жорстокості щодо них.

Цікавим у контексті цього дослідження видається питання правового статусу тварин та теорії визнання їх квазісуб'єктами. Незважаючи на те, що законодавчо тварина безапеляційно віднесена до об'єктів права, дискусійні питання щодо можливості наділення ії певним обсягом правоздатності так чи інакше акцентуються у характеристиці тварини в праві.

3 найдавніших часів тварин сприймали саме як об'єкт, над яким людина могла панувати та користуватися ним. Це було наслідком не обмеженого розуміння їхніх пізнавальних та чуттєвих можливостей, а скоріше спиралося на усвідомлення, що без експлуатації тварини людина не зможе забезпечити власний розвиток. Тобто первісні уявлення про тварин базувалися не на принциповому неправильному уявленні про їхні можливості, а на простому, але потужному твердженні, що виживання та прогрес людської цивілізації безпо- середньо залежали від одомашнення та використання тварин. Протягом тривалого періоду історії в різних народах та культурах ставлення до тваринного світу, в тому числі в правовому аспекті, зазнавало різних деформацій, змінювалося залежно від змін в основоположних підвалинах життя та еволюції людської свідомості, призводячи часом до докорінної трансформації соціальних інститутів [5].

Для того щоб на належному рівні здійснити оцінку зазначених позицій та встановити перспективи сучасних реформ, необхідно перш за все дослідити історично сформовані правила, які становили фауністичне право.

За традиційними концепціями фауністичного права тварини зазвичай розглядалися як об'єкти прав, наданих їх власникам, але не як власники прав людини. Проте навіть як об'єкти тварини історично посідали значиме місце в загальній системі правових та соціальних відносин. Тварини в минулому являли значно більшу частку суспільного багатства, ніж нині. Як зазначає Джаред Даймонд, великі домашні тварини мали вирішальне значення для тих людських об'єднань, які ними володіли, адже вони забезпечували м'ясом, молочними продуктами, добривами, наземним транспортом, шкірою, плуговою тягою та вовною. Дрібніші тварини, такі як птахи, також були одомашнені задля їх м'яса, яєць та пір'я. У господарствах, у яких не вистачало механічних чи електричних джерел живлення, тяглові тварини розглядалися не лише як джерела їжі, але часто були предметами капіталу нарівні із землею і рабами [3].

Обґрунтування правового становища тварин деякими прогресивними вченими не може спиратися на сумнівне припущення, що нове розуміння тварин виправдовує перегляд старих правових устоїв. Стародавні люди, можливо, мало що знали про тонкощі поведінки тварин, та все ж їхнє розуміння особистості тварини, їхнє розуміння схильностей та психічних станів, їхніх навичок одомашнення спростовує те, що вони мали труднощі у тому, щоб відрізнити тварин від неживих предметів.

Сучасні дискусії про тварин виходять за рамки попередніх історичних аргументів, 
під час вирішення цієї суперечки деякі дослідники використовують тісний зв'язок між рабами і тваринами в стародавньому світі. Зважаючи, що несправедливість стосовно рабів мала бути порівняна з несправедливістю щодо тварин. Таким чином, Стівен Уайз починає зі спостереження, що Аристотель об'єднував тварин з рабами і жінками як істотами, які були нижче, ніж грецькі чоловіки у соціальній ієрархії. Він зазначає, що Аристотель зауважив, що «бик - це раб бідної людини». Тепер, коли виправлені помилки, пов'язані з рабами і жінками, необхідно виправити людську несправедливість стосовно тварин [5].

Проте навіть до зміни, з плином часу, формального юридичного статусу було 6 помилкою припускати, що з рабами поводилися як з вільними жінками і що до тварин ставилися так само.

Історично усунення спочатку рабства, а потім громадянської недієздатності для жінок відбулося задовго до нинішньої агітації за зміну статусу тварин. Причому природні когнітивні й емоційні обмеження тварин, навіть вищих тварин, виключають будь-яке створення повного паритету. Якій тварині може бути надано право на укладення договору, для надання свідчень в суді, право голосувати на виборах, брати участь у політичних дискусіях? Ніщо з цього не має жодного сенсу через відсутність внутрішніх здібностей тварин.

Захист від фізичного насильства або, можливо, дещо ширше право, відповідно до якого тварини не можуть бути використані як ресурси, право не розглядатися як речі, що належать людям, - це допустимий максимум [14, с. 8$]$.

Професор філософії Гарвардського університету Роберт Нозік приділяє багато уваги цьому питанню. Його спосіб аргументації працює таким чином. Спочатку він розвиває тему моральних побічних обмежень, які відображують наше роздільне існування, роблячи висновок, що не може бути виправданою жертва одних з нас заради інших. Це розуміння призводить швидше до либертаріанської сторони обмеження проти агресії. Щоб з'ясувати, наскільки сильне це обмеження, Нозік звертається до моральних побічних обме- жень, які мають бути встановлені через те, що тварини є розумними істотами.

3 іншої точки зору розглядає це питання Стівен Уайз, використовуючи теорію пізнання та висуваючи твердження про те, що обмежені пізнавальні здібності підтримують твердження про негативні права, тобто про те, що права не мають використовуватися факторами для людської переваги [5].

«Звільнення тварин» Пітера Сінгера, наприклад, спростовує твердження Декарта про те, що у тварин немає інтересів, тому що вони не розумні. Філософ стверджує, що інтереси людей і тварин мають ураховуватися однаково з моральної точки зору, тому що обидва мають здатність страждати, зазнавати болю і відчувати задоволення [4, с. 13].

Р. Неш, використовуючи різноманітні аргументи, від філософських до політичних, у своїй роботі намагається довести думку про те, що дика природа (у тому числі тварини) мусить мати моральні права на життя, свободу та щастя, зокрема, дика тварина мусить мати право на життя, право на свободу від людського втручання, право на захист від непотрібного страждання, право на продовження життя, право на здорову середу проживання, право на прагнення до щастя, право на реалізацію еволюційного потенціалу тощо [11, с. 5].

Віднайшло філософське осмислення і питання класифікації тварин у категорії власності. Тварини юридично класифікуються як власність у більшості країн світу це спадщина давніх систем права. Однак з тих пір наукові, філософські та культурні уявлення про тварин змінилися, тож має сенс переглянути доцільність майнового статусу тварин.

На думку деяких дослідників сучасності, обґрунтування для класифікації тварин як власності $є$ слабким, і тому необхідно розпочати діалог про альтернативні варіанти їх правового статусу.

Прихильники такої концепції стверджують, що сам факт того, що тварина біологічно не належить до людського виду, не перешкоджає тому, щоб ії̈ класифікували як суб'єкт права. Низка країн фактично почали вивчати цю можливість. Зокрема, 
в деяких місцевостях робилися спроби вирішити проблеми, пов'язані з класифікацією тварин як майна, шляхом створення для них окремого правового статусу.

Цивільні кодекси Австрії, Німеччини та Швейцарії містять положення, які безпосередньо стосуються правового статусу тварин. Наприклад, стаття 285 Цивільного кодексу Австрії, яка почала діяти в 1988 році, передбачає, що «тварини не $\epsilon$ об'єктами, вони захищені спеціальними законами». Крім того, він передбачає, що закони, які стосуються об'єктів, «не застосовуються до тварин, якщо немає суперечливих положень». Аналогічні положення $\epsilon$ в Цивільних кодексах Німеччини та Швейцарії $[1 ; 2]$.

Аналізуючи ці положення, можна все ж стверджувати, що хоча на перший погляд ці положення змінили правовий статус тварин у цих країнах, однак це не зовсім так. Хоча ці положення змінили ступінь, в якому тварини підкоряються закону про об'єкти, вони не зайшли так далеко, щоб віднести тварин до категорії «осіб».

Зокрема, стаття 641а Цивільного кодексу Швейцарії створила окрему категорію для тварин, відмінну від предметів і людей. Тобто тварини більше не $\epsilon$ об'єктами, але вони не $\epsilon$ і носіями прав. Новий закон просто встановлює, що тварини більше не $€$ об'єктами. Очевидною $€$ відсутність визначення, яке роз'яснює їх конкретний правовий статус. Незважаючи на те, що намір законодавця полягав у тому, щоб поліпшити правовий статус тварин, більшість «спеціальних правил», що стосуються тварин насамперед поліпшують правове становище власника або зберігача тварини, а не її самої. Відповідно, стаття 641а носить переважно декларативний характер, введення окремої правової категорії для тварин ніколи не передбачалося [5].

Хоча в цих положеннях йдеться, що закон про об'єкти не застосовується до тварин, для яких $є$ особливі закони, посилаючись на закони про захист тварин, вони допускають застосування законів про власність, якщо відповідного закону про тварин немає. Іншими словами, якщо немає законів, що регулюють відносини людини з тваринами, то тварини продовжують підкорятися закону об'єктів.
Тварини, таким чином, не набули правосуб'єктності і не отримали людей, які доглядають за ними або опікунів замість власників. Звичайно, закон говорить, що вони більше не $є$ об'єктами, але здебільшого вони все ще розглядаються як такі.

Інші підходи до зміни правового статусу тварин шляхом судового втручання використовуються в низці інших країн, у тому числі в Румунії, США та Аргентині.

У 2013 році Проєкт щодо захисту прав тварин «Nonhuman Rights Project» подав до суду Нью-Йорка від імені Томмі клопотання про видачу наказу habeas corpus щодо шимпанзе, якого тримають у неволі. Щоб отримати цей наказ, важливо довести, що позивач $є$ суб'єктом права. На підтримку своєї петиції були представлені письмові свідчення експертів, які доводять, що шимпанзе мають складні когнітивні здібності, які задовольняють вимогам загальноприйнятої концепції особистості і з цього випливають його права на захист від тілесних ушкоджень.

Суд відхилив доводи NhRP, і судовий наказ був відхилений. Два аналогічні клопотання були зроблені від імені трьох інших шимпанзе, яким також було відмовлено. Апеляції були подані до Апеляційного відділу Верховного суду штату Нью-Йорк в усіх справах. У справі Томмі апеляційний суд, що складався 3 п'яти суддів, відхилив апеляцію на тій підставі, що право на свободу не доступне особі, яка не здатна брати на себе обов'язки і відповідальність [6, с. 79].

Незважаючи на особливе загострення цього питання останніми роками, проблема визнання тварини суб'єктом правовідносин не $\epsilon$ принципово новою для світової та вітчизняної науки. Ще наприкінці XIX сторіччя Я. Канторовичем була підготовлена монографія «Процессы против животных в средние века». Сама назва наукової праці вимагає прийняти до відома те, що тварина виступає суб'єктом відповідного процесу (цивільного або кримінального), а отже, може бути прирівняна до суб'єкта права. Як зауважує автор, уперше судові процеси проти тварин зустрічаються у XIII сторіччі, хоча, вочевидь, вони мали місце й раніше, але в архівах не залишилось документального 
підтвердження цьому [12, с. 4]. В Україні, на території Карпат, своєю чергою, існували суди над ведмедями, тобто ведмідь знову ж таки фактично визнавався суб'єктом правовідносин [8, с. 72].

Відповідно до сучасної вітчизняної правничої позиції тварини суб'єктами права бути не можуть. Не змінює цього й норма про заповідальне покладання на одного або декількох спадкоємців обов'язку утримувати домашніх тварин, які належали заповідачеві, а також здійснювати необхідний нагляд і догляд за ними. Юридична енциклопедія суб'єктом права визначає фізичну або юридичну особу, яка $\epsilon$ учасником національних чи міжнародних правовідносин [15, с. 138]. Енциклопедія цивільного права України, своєю чергою, деталізує, що суб'єктами цивільного права $\epsilon$ фізичні особи, юридичні особи та публічно-правові утворення [9, с. 216]. Тобто тварина до переліку суб'єктів цивільного права не належить, і відповідно, в статусі учасника цивільно-правових відносин перебувати не може - наприклад, як уже зауважувалось вище, тварина не може бути учасником спадкового правовідношення, а може бути тільки частиною спадкової маси, яка підлягає належному догляду.

Інколи на теренах науково-публіцистичного інформаційного простору висловлюється думка про захист прав тварин, а отже, й визнання за тваринами відповідних прав унаслідок прийняття Верховною Радою України Закону «Про захист тварин від жорстокого поводження» [13].

Утім, імплементація у сучасні реалії зазначеного нормативно-правового акта пролобійована скоріш загально гуманістичною спрямованістю права та намаганням зміцнити засади моральності у суспільстві. Самі норми Закону України «Про захист тварин від жорстокого поводження» [13] уникають навіть натяку на можливість застосування формулювання «право тварини на...».

Висновки і пропозиції. Як показує проведене дослідження, правове становище тварин не завжди й не у всіх правових системах отримувало сталий статус об'єкта правовідносин. Окремі ознаки, що вирізняли їх із загального кола правових об'єктів тією або іншою мірою проявля- лися у різноманітних джерелах протягом доволі довгих історичних періодів. Нині ці процеси розгортаються з новою силою: зоозахисники у США мають можливість подавати від імені тварин позови до суду, у деяких штатах США вони можуть бути носіями авторських прав, країни східного світу встановлюють особливий статус для дельфінів, корів, панд.

Розвиток суспільної свідомості різних держав, готовність соціуму до локальних перетворень перебуває на різних рівнях, навіть незважаючи на сучасний стан інформатизації й посилені процеси гармонізації. Сучасній українській правовій сфері не притаманні тенденції до змінювання чи корегування статусу таких об'єктів прав, як тварини, однак, прогностична функція права одним зі своїх основних призначень якраз і має створення умов для формування нових, зумовлених реаліями людського буття і економіки відносин. Більшою мірою найбільш раціональним варіантом вирішення обговорюваної дискусії вважають збереження поточного статус-кво тварин. За переважаючою думкою вони виключаються з числа суб'єктів права через відсутність у них здатності до розумного мислення. Однак випадки вчинення дельфінами та китами суїцидів навряд чи можна однозначно вважати просто збоями їхніх геомагнітних компасів. Безумовно, цей момент $\epsilon$ дуже дискусійним, але можливий і розвиток інших правовідносин у майбутньому. Наявність же у тварин ознак, що виділяють їх з ординарного розуміння об'єкта правовідносин, притаманність їм атрибутів квазісуб'єктності $\epsilon$ цілком допустимими.

\section{Список використаної літератури:}

1. Austrian Civil Code, art 285, Adopted on 1811. URL: https://www.jusline.at/gesetz/ abgb/paragraf/285a.

2. German Civil Code, $\S 90 a$ Adopted on 2 January 2002. URL: https:// www.gesetze-iminternet.de/englisch_bgb/ englisch_bgb.html\#p0272.

3. Jared Diamond, Guns, Germs, and Steel: The Fates of Human Societies. Human Ecology Review, Vol. 14, No. 2, 2007. URL: https://www.humanecologyreview.org/ pastissues/her142/yorkandmancus.pdf.

4. Peter Singer. Animal Liberation. Harpercollins, revised ed., 2002, P. 10-15. 
5. Richard Epstein. Animals as Objects, or Subjects, of Rights, in Cass $R$ Sunstein and Martha C Nussbaum (eds), Animal Rights: Current Debates and New Directions. Oxford University Press, 2004. P. 143. URL: https://papers.ssrn.com/sol3/ papers.cfm?abstract_id=359240.

6. Robert Garner "Political Ideology and the Legal Status of Animals". 2002. 8 Animal Law 79-80. URL: https://www. tier-im-fokus.ch/wp-content/uploads/ 2009/09/garner02.pdf.

7. Борейко В.Е. Экологические традиции, религиозные воззрения славянских и других народов. Т. 1. Киев : Киевский эколого-культурный центр, 2003. 160 с.

8. Васидлов Ю. Українське народне коріння концепції прав природи. Закон «Про захист тварин від жорстокого поводження». Український прорив. Київ: Київськийекологокультурнийцентр, 2007. 88 с.

9. Енциклопедія цивільного права України. / відп. ред. Я.М. Шевченко; Ін-т дер- жави і права ім. В.М. Корецького НАН України. Київ : Ін Юре, 2009. 952 с.

10. Капытина Т.П. Защита животных в эпоху Древнего Мира. Вопросы исторической науки: материалы III Междунар. науч. конф. (Москва, январь 2015 г.). Москва : Буки-Веди, 2015. С. 69-78. URL: https:// moluch.ru/conf/hist/archive/128/7034.

11. Нэш Р. Права природы. История экологической этики. Киев : Киевский экологокультурный центр, 2001. 166 с.

12. Канторович Я. Процессы против животных в средние века. Санкт-Петербург : Юрид. б-ка, ценз. 1897.58 с.

13.Про захист тварин від жорстокого поводження : Закон України від 21.02.2006 № 3447-IV. Голос України. 2006. 05 трав. № 82.

14. Сингер П. Человек и животное равны. Гуманитарный экологический журнал. 2003. Т. 5. Спецвыпуск. С. 8-9.

15. Юридична енциклопедія : в 6 т. / ред. кол.: Ю.С. Шемшученко та ін. Київ : Укр. енцикл., 1998. Т.: А-Г. 672 с.

\section{Shehovtsov V. Philosophical and historical aspects of the transformation of public consciousness in relation to the animal world as an object of environmental law}

The article explores the specific legal and philosophical aspects of the formation of approaches to the general understanding of animals as objects of legal relations, the cases of their granting in certain socio-historical periods additional qualities that go beyond the doctrine of the objects of rights.

Despite the fact that the animal is legally referred to as objects of law, debatable questions about the possibility of granting it a certain amount of legal capacity in one way or another are emphasized when characterizing the animal in law.

It has been established that under traditional concepts of faunistic law, animals are usually regarded as objects of rights conferred on their owners, but not as holders of human rights. However, even as animal objects, historically they have occupied a significant place in the overall system of legal and social relations. Animals in the past represented a much larger share of public wealth than today.

It is concluded that with philosophical thinking and questions about the classification of animals in the property category. Animals are legally classified as property in most countries of the world - a legacy of ancient systems of law. However, since then scientific, philosophical and cultural ideas about animals have changed, so it makes sense to review the appropriateness of the property status of animals.

The study shows that, according to some researchers, the rationale for classifying animals as property is weak, and therefore a dialogue on alternative options for their legal status is needed. Proponents of this concept argue that the more fact that an animal is not biologically related to the human species does not prevent it from being classified as a subject.

It is concluded that according to the current domestic legal position animals cannot be eligible. Even today, the current Ukrainian legal sphere does not tend to change or adjust the status of such objects of rights as animals, because they are overwhelmingly excluded from the rights of subjects because of their lack of reasoning ability. However, the presence of features in animals that distinguish them from the ordinary understanding of the object of the relationship, the inherent attributes of quasi-personality attributes is quite acceptable.

Key words: fauna, animal life, environmental law object, quasi-entity, animals as subjects, animal legal capacity, philosophical analysis of the legal status of animals. 